\title{
3D Technological Readiness: A Northern Cyprus Perspective
}

\author{
https://doi.org/10.3991/ijes.v5i4.7737 \\ M. B. Nawaila ${ }^{(\varpi)}$ \\ College of Education Azare, Nigeria. \\ yaahkake@gmail.com \\ Huseyin Bicen \\ Near East University, Cyprus.
}

\begin{abstract}
In the past years, considerable effort has been made towards integrating technological enhancement and support for learning, these technologies have not only impacted the field of education, but have also expanded and challenge our thinking of what constitute a learning environment.

In spite of the fact that the world is without a doubt three dimension, we are always inclined to teach by utilizing two dimensional technology, which we know is static and offers no powerful substance, but since we trust it to be more adaptable, more helpful and less expensive.

This research is a quantitative research that explores the use of two different questionnaires to access the level of 3D technological readiness and general technological readiness among students of the Turkish Republic of Northern Cyprus and all analysis were done using SPSS version 20 software.

The questionnaires were both found to be reliable with Cronbach's Alpha .730 for $3 \mathrm{D}$ technological questionnaire and .783 for the general technology questionnaire

It was found that the students are ready for the implementation of $3 \mathrm{D}$ technology in education with mean $=3.5403$ and that they are undecided when it comes to general technological readiness with mean $=3.427$ which was attributed to the ambiguous nature of the word technology.

No significant difference was found in terms of readiness between the two genders, but Civil Engineering Department students are more ready. A significant positive correlation was found between the two questionnaires
\end{abstract}

Keywords-3D, Readiness, Technology

\section{$1 \quad$ Introduction}

In the past years, considerable effort has been made towards integrating technological enhancement and support for learning, this technology has not only impacted the field of education, but have also expanded and challenge our thinking of what constitute a learning environment 
Not only that the learning environment have incorporated computers or the internet, but also simulations, games, smart phones and later 3D technologies [1].

Three Dimensional technologies otherwise known as 3D technologies, according to Collins Dictionary, refer to different types of technologies that provide three dimensional visual appearances and unlike a textbook are able to add many layers and bring unprecedented depth to what is being learned.

It is no magic that modern students' lives in the world of multimedia where the utilization of video as an essential type of interaction and correspondence, policy makers, researchers, and teachers alike are searching for means to bring forth information to the student that will motivate and encourage them to scrutinize subjects fully. Reasonable investigation more often than not, provides better coherence and understanding, which eventually may lead to greater achievement by the students

As stipulated by Osberg [2] in itself, technology cannot enhance education, and to be viable, even the most promising educational methodology requires effective and skillful application.

\section{Aims}

To access student's readiness for the integration of 3D technologies in their classroom, in doing so, we will also see the limitations and the possible advantages of using $3 \mathrm{D}$ technology and also access the acceptance ratio between the genders, age groups, departments and level of education

\section{$3 \quad$ Literature Review}

The popularity of 3D technology has never been greater more importantly, the technology to support it has never been as sophisticated, the use of $3 \mathrm{D}$ in education is used by either of the three methods:

As of late, unique 3D Immersive recreations have been associated with different educational fields, and particularly in mathematics, physics and engineering as a contrasting option to traditional non-immersive display [3]. An immersive Virtual Environment includes human computer communication inside the space [4]. A noteworthy quality of 3D immersive Environments that differentiate them from non immersive $2 \mathrm{D}$ and $3 \mathrm{D}$ is that they include egocentric navigation (where the learner finds himself encompass in the environment) instead of exocentric route (in this case, the learner finds himself not included in the environment) $[1,5]$.

\subsection{Virtual reality}

The meaning of virtual reality (VR) was coined from the meaning of the word "virtual" and 'reality'. "Virtual" is said to mean close and "Reality" is what we encountered as individuals. So the term "virtual reality" essentially signifies 'close reality'. 
This could, obviously, mean anything beside it more often than not means a particular sort of reality emulation.

According to dictionary.com "Virtual reality is the computer-generated simulation of a three-dimensional image or environment that can be interacted with in a seemingly real or physical way by a person using special electronic equipment, such as a helmet with a screen inside or gloves fitted with sensors."

The basis for the virtual reality idea is that synthesis can be done by computer in a $3 \mathrm{D}$ environment with the utilization of visual and sound-related gadgets [6] so that the human administrator can relate to the environment as though he is a part of the environment

Virtual Reality in a more technical term is the utilization of Computer technology to generate a simulated environment. Virtual Reality, puts the user inside the experience, Rather than just being spectators, clients are immersed and capable of relating to the $3 \mathrm{D}$ universe, By simulating as many senses as possible

\subsection{Virtual Reality in Education}

Virtual Reality epitomizes an up-and-coming field with high capability for improving and changing the learning experience, while in the past confined to medical, industrial and security applications, but with freedom, presence and interconnections, virtual environment can give an intelligent appealing and challenging educational setting, supporting pragmatic learning.

Currently, various platforms were designed to guide instruction and learning, for example, using a Virtual Environment to teach physics was researched by researchers of George Mason University and the University of Houston

\subsection{Augmented Reality (AR)}

Like VR, AR has been defined and classified differently by different scholars, Azuma [7] sees it as different from virtual reality, some authors perceive Augmented Reality as an extraordinary form of Virtual Reality, whereas some authors stated that Augmented Reality is a more generic approach and sees Virtual Reality as an extraordinary form of Augmented Reality.

Augmented Reality Is when elements of the original surroundings are supplemented by sensory input generated by a computer, this input may include sound, video, graphics or GPS data.

\subsection{Augmented Reality in Education}

In educational, AR has served as an aid to standard curriculum, graphical design, audio and video were added to student's environment synonymously. Books and lots of other instructive reading material may contain triggers that AR gadget will use for scanning and extra information delivery to the students presented in the form of multimedia. [8] 
As Augmented Reality advances students could engage each other in real time, historical occasion's recreation using computer generated simulations [8]. On tertiary institutions, applications can be utilized to promote learning, Construct3D, can be used by the students to learn mechanical engineering [9]. Chemistry AR app, can be utilized by the students to relate to molecular structures, medical students could interact with different human parts in [10].

\subsection{Mixed Reality}

Mixed Reality (MR) also known as Hybrid reality is the fusing of the real and virtual world to create new surrounding and visualization where physical and computerized objects exist together synonymously. Although more advance than VR because of the number of technologies involved, MR employed the best aspect of VR and AR.

Mixed Reality works by checking the real environment and making a 3D guide of your environment so the gadget understands precisely how and where to put the computerized content into the space at the same time enabling you to relate with it utilizing sign or gestures.

\subsection{Mixed Reality Education}

Practical application of mixed reality in education has been cited by various researchers most notable is project Esper designed and implemented by $3 \mathrm{~d} 4 \mathrm{medical}$ with over 12 million users, Esper is an anatomy class designed using mixed reality.

\subsection{D Printing}

Another 3D technology gaining high popularity is 3D Printing, 3D printing may sound like in the movies, but the procedure is rather similar to CNC machine with the only difference being printed instead of cutting, instead of using ink, the 3D printer employs the use of greater amount of substantive metal, rubber, materials-plastics and other similar materials, although not as strong, intricate or functional as the real-world equivalent.

\subsection{D printing in Education}

$3 \mathrm{D}$ printing can be used by various students for instance teachthought.com sight the following as the use of3D printing in education, engineering students can print prototypes, history students can print historical artifacts, geography students can also print topography or demography etc, yet, 3D printing is an exciting and innovative technology, with various innovative and real-life application although it has multiple advantages ranging from producing learning materials to improved learning methodology but the acceptance is rather low due to the cost implication involved in the process (source www.blackcountryatelier.com). 
Various scholars have written extensively on 3D technologies, for instance, Mantovani [11] cite the existence of the possibility of virtual reality in contributing to education, therefore, in his work, he discuss the ideas and advantages of virtual reality usage in education and training, in another work, [12] develop AquaMOOSE, a 3D graphical environment, motivated by the high usage of video games, the researchers' design a video game type of learning environment that aims to engage students to explore mathematics in a different way, unlike the conventional classroom, at the end no statistically significant improvement was noticed in the students, performance which the researchers based on high student's expectation on the software.

Kaufmann \& Schmalstieg [13] in their research design Construct3D a geometric designing tool in $3 \mathrm{D}$, to be used in mathematics and geometry education, using mobile augmented reality. The students find the software easy to use and the software was also found to improve spatial skills. While [14] in his work provide an aid to teaching astronomy by designing a virtual environment using 3D technology of the Solar System, Martin-Gutierrez, Saorin, Contero \& Alcaniz et al [15] in their work design an augmented reality application for improving understanding, reasoning and remembering abilities of engineering students named AR-Dehes and used on short term remedial mechanical engineering students, AR-Dehes shows remarkable improvement on student's performance.

In another design work, Pan, Cheok, Yang \& Zhu, et al, [16] considered educational application of virtual learning environment to make a comprehensive review on virtual learning environments and found out that, they can be used to promote, encourage and motivate learners in a fast and exciting way.

\section{$4 \quad$ Relevant Studies}

Various researchers have worked extensively in one way or the other to access the readiness of individuals, schools, institutions firms, and even countries to technology for instance, Richey, Daugherty, \& Roath [17] in their research works on the relevance of technological readiness and technological complementarity in the management of supply it quality and performance where they found them to be of immense importance, when it comes to competency and performance and they conclude by displaying to firm leadership the method of controlling technology across the partnership.

Wang, Chen and Fang [18] on the other hand, consider the use of cell phone based learning to examine the integration of cell phone learning in a conventional classroom at the end of the study they found no trace of technological anxiety and that the students found the class motivating which means cell phones can actually be integrated into their classroom.

Reeves and $\mathrm{Li} \mathrm{[19]} \mathrm{in} \mathrm{their} \mathrm{research,} \mathrm{investigate} \mathrm{one} \mathrm{of} \mathrm{the} \mathrm{stumbling} \mathrm{blocks} \mathrm{of}$ online professional development (OPD) among United States elementary school teachers which is technological readiness for OPD they found the educators to possess the desired computer knowledge and that they think online OPD are as motivating as 
face-to-face OPD. They also found some issues that need looking into among teachers.

Shariq, Richard, Scott, Ann, Casebeer. Et al [20] the teams in their work, tries to access the health institutes readiness with the expected change related to events related to ICT his research bring forth the readiness assessment tool design for health institution in third world countries, different tools were designed for different teams e.g. managers and health care providers, whereas, Caison, Bulman, Pai, \& Neville, [21] In their research adopt the technological readiness index to access the readiness for technology among nursing and medical students. Their result shows that the village nurses are more insecure than the city nurses when it comes to technology male student doctors are more creative and exhibit high readiness than the females and older medical students (over 25) have a negative readiness score unlike the younger once.

Touré, Poissant \& Swaine [22] in their work make a quantitative research with the aim of examining the readiness for e-health among the personnel of a rehabilitation center in Canada a questionnaire was administered to the personnel result shows that respondent thinks they are ready and wants technology but thinks their environment is only half ready.

Kottemann [23] in his work displays a crucial hypothetical model and acknowledge new elements with his end goal is to investigate the impacts of three logical factors, technological readiness, institutional preparation and financial preparation for online government services across nations were huge impact was noticed, where on the other hand, Abdalla, Ibrahim, \& Ahmed [24] works with the sole purpose of examining and analyzing the United Arab Emirate performance in worldwide competitiveness and technology readiness his paper basically look at the effect of ICT and training on enhancing technological readiness in the UAE, he discovered that the UAE has gained essential grounds.

Brach [25] believes that technology is generally perceived as a key driver of reasonable financial improvement, he therefore centered his paper to concentrate on development and mechanical advancement in the MENA district of Egypt and tried to access whether they are ready for the development.

Hussin, Manap, Amir, \& Krish [26] tried to access the readiness of students from two different Malaysian Universities, their readiness in terms of skills psychology and finance using an online questionnaire. The result shows high computer experience and students wants the integration, but not sure of the cost involved, meanwhile, using the same country, Ismail, Azizan, \& Gunasegaran [27] present a quantitative research to access Malaysian students' mobile learning readiness and obtain a fair result which shows that students are only half way ready although some were afraid of the cost that may be involved but want to know what mobile learning is. 


\section{$5 \quad$ Methodology}

\section{$5.1 \quad$ Setting}

This study was descriptive in nature and in order to gather primary data, 50 students from the Engineering faculty of 6 universities of the Turkish republic of northern Cyprus were selected at random these Universities are Near East University (NEU), Eastern Mediterranean University (EMU), Cyprus International University (CIU), Girne American University (GAU), European University of Lefke (EUL) and University of Kyrenia (UK).

A stratified random sampling method was used, where the University form the strata.

\section{$5.2 \quad$ Instrument}

For the purpose of this research, two questionnaires were used, the first questionnaire was developed by the researchers consisting of 2 sections, personal information section containing 7 questions and $3 \mathrm{D}$ readiness section containing 11 questions and for technological readiness, technology readiness index (TRI) as proposed by Parasuraman [28] was adopted, both questionnaires employ the use of 5 point Likert scale ranging from strongly agree (5) to strongly disagree (1) all analysis will be done using SPSS version 20.

\subsection{The demography of the respondents}

Table 1 shows the gender classification among the respondent, with 167 (55.7\%) being males and the remaining $133(44.3 \%)$ being females, it can also be seen that, majority of the respondents are between $19-21,176(58.7 \%)$ followed by greater than 21 years of age, 81 (27\%) lastly less than 19, having 43 (14.3\%). The table also depicts classification according to departments, although all the respondents are from the engineering faculty, Electrical engineering department has the highest representation with $92(30.7 \%)$, then civil engineering with $73(24.3 \%)$, then mechanical engineering having $60(20 \%)$, followed by computer engineering department with 46 $(15.3 \%)$ and lastly other (all other courses in engineering faculty put together) with 29 (9.7\%). With regards to level, level 2 has the highest representation with $111(37 \%)$, then level 3 with $84(28 \%)$, then level 4 with $57(19 \%)$, then level 1 with $46(15.3 \%)$, Lastly level 5 with only $2(0.7 \%)$ representatives. Lastly, the table also shows the classification with regards to origin, from Northern Cyprus is an occupied part, the Cypriots has 219 (73\%) and Turkish has 81 (27\%).

Table 2 shows the reliability statistics of both the two questionnaires, which has both past the minimum of (0.60) as stipulated by Kline [29], hence, all variables are assumed to be reliable. 
Table 1. showing respondents demography

\begin{tabular}{|l|c|}
\hline \multicolumn{1}{|c|}{ Variable } & N (\%) \\
\hline Gender & $167(55.7)$ \\
\hline Male & $133(44.3)$ \\
\hline Female & $43(14.3)$ \\
\hline Age & $176(58.7)$ \\
\hline Less than 19 & $81(27)$ \\
\hline $19-21$ & \\
\hline Greater than 21 & $73(24.3)$ \\
\hline Department & $46(15.3)$ \\
\hline Civil Engineering & $92(30.7)$ \\
\hline Computer Engineering & $60(20)$ \\
\hline Electrical Engineering & $29(9.7)$ \\
\hline Mechanical Engineering & $46(15.3)$ \\
\hline Others & $111(37.0)$ \\
\hline Level & $84(28.0)$ \\
\hline 1 & $57(19.0)$ \\
\hline 2 & $2(0.7)$ \\
\hline 3 & \\
\hline 4 & $219(73)$ \\
\hline 5 & $81(27)$ \\
\hline Origin & \\
\hline Cypriot & \\
\hline Turkish & \\
\hline & \\
\hline
\end{tabular}

Table 2. Showing the reliability of the questionnaires

\begin{tabular}{|l|c|}
\hline \multicolumn{1}{|c|}{ Variables } & Cronbach's Alpha \\
\hline 3D Readiness & .730 \\
\hline Technological Readiness & .783 \\
\hline
\end{tabular}

\subsection{Students Readiness to 3D Technology in Education}

After a descriptive analysis on the respondents readiness on the use of 3D technology in education, it was found that most of them knows what 3D technology in education is, with mean $=3.8433$ and STD $=1.09061$, the students would like to learn with $3 \mathrm{D}$ technologies because the opportunities are limitless also get a high acceptance with mean $=3.8133$ and STD $=0.94240$, although majority of the students are not ready for the integration now was a surprise, with mean $=3.1767$ and $\mathrm{STD}=0.99772$, many students want to know more about $3 \mathrm{D}$ technology with mean $=3.7300$ and STD $=0.97995$ and interestingly, many of the students are willing to pay extra if $3 \mathrm{D}$ technology will be intergrated into their class with mean $=3.4067$ and STD $=0.04764$ which shows interest of the students to $3 \mathrm{D}$ technology in education. The students also 
want $3 \mathrm{D}$ technologies as a complement to their conventional classroom with mean $=$ 3.5067 and STD $=1.06408$.

A total mean of 3.5403 which is considered very close to agree means that the students can be considered ready although not strongly ready for 3D technology in education.

\subsection{Students Technological Readiness}

Like the 3D readiness, descriptive statistics were also carried out on the technological readiness questionnaire to analyze the level of technological readiness among the students.

It was noted that the majority of the students want to use the most advance learning technologies available with mean $=3.4400$ and STD $=1.10626$ but they also think societies should be less dependent on technology with mean $=3.2333$ and STD $=$ 1.01109 and it was also seen that the students keep up with latest technological development in the area of interest, A factor worth note is that the students are always open to learning about different and new technologies which has the highest mean $=3.8100$ and STD $=1.00040$ which is not a surprise judging by the student's responses.

The overall means stand at 3.427 which is more of a neutral view which might happen because of the openness or ambiguous the word technology is.

The study shows no significant difference between the genders with regards to both $3 \mathrm{D}$ technology readiness in education and general technological readiness in education with $\mathrm{F}(.111)=298 \mathrm{P}=0.912$ and $\mathrm{F}(1.543)=298 \mathrm{P}=0.124$ respectively as can be seen in table 5 , but a significant difference was noticed in both 3D technological readiness among the students, were students with Cypriotic origin being much more ready than those with Turkish origin with $\mathrm{F}(3.030)=298, \mathrm{P}=0.003$ and $\mathrm{F}(3.070)=126.769$ $\mathrm{P}=0.003$ for both $3 \mathrm{D}$ technological readiness and general technological readiness respectively, as can be seen in table 6 .

Table 3. Showing Means and Standard deviation of students' response to 3D questionnaire

\begin{tabular}{|l|c|c|}
\hline \multicolumn{1}{|c|}{ Items } & Mean & $\begin{array}{c}\text { STD. } \\
\text { Deviation }\end{array}$ \\
\hline I know what 3D technology in education is? & 3.8433 & 1.09061 \\
\hline I want to know more about 3D technology in learning & 3.7300 & .97995 \\
\hline I would prefer conventional learning than using 3D technologies & 3.6467 & 1.0640 \\
\hline $\begin{array}{l}\text { I don't mind paying extra money if 3D technologies will be integrated into } \\
\text { my class }\end{array}$ & 3.4067 & 1.0319 \\
\hline Integration of 3D into my class will make my life difficult & 3.1900 & 1.0476 \\
\hline I am not ready for 3D technologies if my university integrates them now & 3.1767 & .99772 \\
\hline $\begin{array}{l}\text { I will like my lecturers to integrate 3D technologies into my class as addition to } \\
\text { face to face conventional classroom }\end{array}$ & 3.5067 & 1.0198 \\
\hline $\begin{array}{l}\text { I am afraid of the additional cost that may come with 3D technology } \\
\text { integration in my classroom }\end{array}$ & 3.3433 & .94256 \\
\hline I will like my lecturers make my classes only using 3D technologies & 3.5467 & .97861 \\
\hline I think 3D technologies are good for me & 3.7400 & .89166 \\
\hline I would like to learn with 3D technologies because the opportunities are limitless & 3.8133 & .94240 \\
\hline
\end{tabular}


Paper-3D Technological Readiness: A Northern Cyprus Perspective

Table 4. Showing Means and std of students' response to Gen. Tech. questionnaire

\begin{tabular}{|l|c|c|}
\hline & Mean & $\begin{array}{c}\text { STD. } \\
\text { Deviation }\end{array}$ \\
\hline Technology gives people more control over their daily lives & 3.5500 & 1.2079 \\
\hline Products and services that use technologies are much more convenient to use & 3.4400 & 1.1062 \\
\hline I prefer to use the most advance learning technologies available & 3.4633 & .98923 \\
\hline Societies should not rely on technologies to solve its problems & 3.2333 & 1.0110 \\
\hline $\begin{array}{l}\text { I find that technology usually design to make life easier usually has } \\
\text { disappointing results }\end{array}$ & 3.0767 & 1.0004 \\
\hline I am among my circle to use any latest technology that is available in the market & 3.3267 & .99830 \\
\hline I can usually figure out high tech products and services without help from others & 3.4700 & .98607 \\
\hline I keep up with the latest technological development in my area of interest & 3.3533 & 1.0158 \\
\hline I enjoy the challenge of figuring out high tech gadgets & 3.5467 & .91137 \\
\hline I am always open to learning about new and different technologies & 3.8100 & 1.1036 \\
\hline
\end{tabular}

Table 5. Showing $T$ test between gender and the readiness

\begin{tabular}{|c|c|c|c|c|c|c|c|}
\hline & F & Sig & $t$ & df & $\begin{array}{l}\text { Sig (2- } \\
\text { tailed) }\end{array}$ & Mean Diff & \begin{tabular}{|c|c|}
$\begin{array}{c}\text { Std error } \\
\text { df }\end{array}$ \\
\end{tabular} \\
\hline $\begin{array}{l}\text { Readiness_3D } \\
\text { Equal Variances } \\
\text { assumed } \\
\text { Equal Variances } \\
\text { not assumed }\end{array}$ & 20.416 & .000 & $\begin{array}{l}.111 \\
.116\end{array}$ & $\begin{array}{l}298 \\
283.837\end{array}$ & $\begin{array}{l}.921 \\
.907\end{array}$ & $\begin{array}{l}.07379 \\
.63359\end{array}$ & $\begin{array}{l}.66557 \\
.63359\end{array}$ \\
\hline $\begin{array}{l}\text { Readiness_Tech } \\
\text { Equal Variances } \\
\text { assumed } \\
\text { Equal Variances } \\
\text { not assumed }\end{array}$ & 29.660 & .000 & $\begin{array}{l}1.543 \\
1.625\end{array}$ & $\begin{array}{l}298 \\
280.390\end{array}$ & $\begin{array}{l}.124 \\
.105\end{array}$ & $\begin{array}{l}1.07933 \\
1.07933\end{array}$ & $\begin{array}{l}.69955 \\
.66405\end{array}$ \\
\hline
\end{tabular}

A one - way between subject ANOVA was conducted to compare departments and levels 3D technology readiness, a significant difference was found with $F(4)=3.016$ $\mathrm{P}=0.018$ for departments and $\mathrm{F}(4)=6.73 \mathrm{P}=0.000$ for levels, multiple comparisons were done using Scheffe between the departments and levels, it was found Civil engineering students are more ready for 3D technology than Computer engineering and Electrical engineering students which can be attributed to the type practicals' that Civil engineering students' needs and the nature of their studies some site can only be seen in pictures. No significant difference was found between Civil engineering students and Mechanical engineering or the remaining departments, no significant difference was also found between Mechanical engineering, Electrical engineering, Computer engineering and other engineering department and vice versa.

In terms of levels significant difference was found between level 2 and level 3 with levels, students showing more readiness likewise level 4 students showing better 
readiness than level 3 students, no significant difference was found between all other levels as can be seen in table 6 .

Table 7 shows another one way ANOVA conducted to compare departments and levels, readiness to general technology and a significant difference was found with $\mathrm{F}(4)=4.018 \mathrm{P}=0.003$ for departments and $\mathrm{F}(4)=6.117 \mathrm{P}=0.000$ for levels.

Using Scheffe it was also found that students of Civil engineering are more ready than students of Mechanical engineering and others, likewise, students of computer engineering showing more readiness than electrical engineering students.

No significant difference was found between Mechanical engineering, Electrical engineering and other engineering.

In terms of level, a significant difference was found only between level 2 and level 3 students likewise level 3 and level 4 students with level 4 students showing more readiness to technology than level 3 students and level 3 exhibiting more readiness than level 2.

After conducting a paired sample t test a significant difference was noticed between the $3 \mathrm{D}$ technological readiness and the general technological readiness with $\mathrm{F}(14.573)=299 \mathrm{P}=0.000$ which can be attributed to the ambiguous nature of the work "Technology".

Table 6. Showing $\mathrm{T}$ test between nationality and the readiness

\begin{tabular}{|r|c|c|c|c|c|c|l|}
\hline & F & Sig & t & Df & $\begin{array}{l}\text { Sig(2- } \\
\text { tailed) }\end{array}$ & $\begin{array}{c}\text { Mean } \\
\text { Diff }\end{array}$ & $\begin{array}{c}\text { Std error } \\
\text { df }\end{array}$ \\
\hline $\begin{array}{r}\text { Readiness_3DEqual Variances } \\
\text { assumed } \\
\text { Equal Variances } \\
\text { not assumed }\end{array}$ & 36.128 & .000 & 3.030 & 298 & .003 & 2.222 & .73356 \\
\hline $\begin{array}{c}\text { Readiness_TecEqualVariances } \\
\text { assumed } \\
\text { Equal Variances } \\
\text { not assumed }\end{array}$ & 3.406 & .066 & 3.283 & 298 & .001 & 2.53458 & .77206 \\
\hline
\end{tabular}

Table 7. Tests of Between-Subjects Effects - Dependent Variable: Readiness_Tech

\begin{tabular}{|l|c|c|c|c|c|}
\hline \multicolumn{1}{|c|}{ Source } & Type III Sum of Squares & df & Mean Square & F & Sig. \\
\hline Corrected Model & $3642.593^{\mathrm{a}}$ & 19 & 191.715 & 7.414 & .000 \\
\hline Intercept & 108892.946 & 1 & 108892.946 & 4211.017 & .000 \\
\hline Department & 415.560 & 4 & 103.890 & 4.018 & .003 \\
\hline Level & 632.761 & 4 & 158.190 & 6.117 & .000 \\
\hline Department* Level & 2164.903 & 11 & 196.809 & 7.611 & .000 \\
\hline Error & 7240.537 & 280 & 25.859 & & \\
\hline Total & 363213.000 & 300 & & & \\
\hline Corrected Total & 10883.130 & 299 & & & \\
\hline
\end{tabular}

a. $\mathrm{R}$ Squared $=.335$ (Adjusted R Squared $=.290$ )

Table 6 Showing one-way ANOVA between 3D readiness, Department and Level 
Table 8. Tests of Between-Subjects Effects - Dependent Variable: Readiness_3D

\begin{tabular}{|l|l|l|l|l|l|}
\hline \multicolumn{1}{|c|}{ Source } & Type III Sum of Squares & \multicolumn{1}{|c|}{ df } & \multicolumn{1}{c|}{$\begin{array}{c}\text { Mean } \\
\text { Square }\end{array}$} & \multicolumn{1}{c|}{ F } & Sig. \\
\hline Corrected Model & $2716.942^{\mathrm{a}}$ & 19 & 142.997 & 5.674 & .000 \\
\hline Intercept & 135022.378 & 1 & 135022.378 & 5357.200 & .000 \\
\hline Department & 304.023 & 4 & 76.006 & 3.016 & .018 \\
\hline Level & 662.690 & 4 & 165.673 & 6.573 & .000 \\
\hline Department * Level & 1162.079 & 11 & 105.644 & 4.192 & .000 \\
\hline Error & 7057.095 & 280 & 25.204 & & \\
\hline Total & 464749.000 & 300 & & & \\
\hline Corrected Total & 9774.037 & 299 & & & \\
\hline
\end{tabular}

a. R Squared $=.278($ Adjusted R Squared $=.229)$

Table 9.

\begin{tabular}{|c|c|c|c|c|c|c|c|}
\hline & $\begin{array}{c}\text { Readi- } \\
\text { ness_3D }\end{array}$ & $\begin{array}{c}\text { Readi- } \\
\text { ness_Tech }\end{array}$ & Gender & Age & $\begin{array}{c}\text { Depart- } \\
\text { ment }\end{array}$ & Level & Nationality \\
\hline $\begin{array}{c}\text { Readi- } \\
\text { ness_3D }\end{array}$ & 1 & & & & & & \\
\hline $\begin{array}{c}\text { Readi- } \\
\text { ness_Tech }\end{array}$ & $\begin{array}{c}.555^{* *} \\
.000 \\
\end{array}$ & 1 & & & & & \\
\hline Gender & .912 & .124 & 1 & & & & \\
\hline Age & .664 & .052 & $\begin{array}{c}-.318 * * \\
.000\end{array}$ & 1 & & & \\
\hline Departmnt & $\begin{array}{c}-.155^{* *} \\
.007\end{array}$ & $\begin{array}{c}-.239 * * \\
.000\end{array}$ & .457 & $\begin{array}{c}-.168 * * \\
.003\end{array}$ & 1 & & \\
\hline Level & .403 & .093 & $\begin{array}{c}-.163 * * \\
.005\end{array}$ & $\begin{array}{c}.450 * * \\
.000 \\
\end{array}$ & .630 & 1 & \\
\hline Nationality & $\begin{array}{c}-.173 * * \\
.003\end{array}$ & $\begin{array}{l}-.187 \\
.001\end{array}$ & .184 & $\begin{array}{c}.241 * * \\
.000\end{array}$ & $\begin{array}{c}-.175^{* *} \\
.002\end{array}$ & .256 & 1 \\
\hline
\end{tabular}

There is a strong positive correlation between 3D technological readiness and general technological readiness which is expected, students that welcome 3D technology are expected to be technological addicts and will welcome majority of the trending technologies, but a slightly negative correlation was found between 3D technological readiness and both department and nationality, likewise, a negative correlation was spotted between general technological readiness and both departments and nationality.

\section{Conclusion}

Learning has never been limited to the classroom, yet modern technology is pushing back the limits of where students can exploit.

In spite of the fact that the world is without a doubt three dimension, we are always inclined to teach by utilizing two dimensional technology, although we know is static 
and offers no powerful substance, but since we trust it to be more adaptable, more helpful and less expensive

The creation of moderate 3D innovation guarantees bringing into reality the fantasies of completely engaged students.

This research work analyzes the readiness to 3D technology and general technology in education by the students of faculty of engineering Northern Cyprus, and it was found that the students are ready for 3D technology integration and somewhat undecided with the general technology readiness which was inclined to the ambiguous nature of the world technology.

The limitation of this research lies in the number of samples used which will not allow for generality, and for future research, we will recommend undertaking the same research in another department or integrating 3D in a classroom and accessing students' performance.

\section{$7 \quad$ References}

[1] I. Dror, Technology Enhanced learning: The good, the bad and the ugly pragmatics cognition 2 (2) John Benjamin publishing company (2002) PP 215 - 223.

[2] K. M. Osberg, Virtual Reality and Education: A Look at Both Sides of the Sword, http://www.hitl.washington.edu/publications/r-93-7/(1992).

[3] V. S. Pantelidis, Reasons to Use Virtual Reality in Education, VR in the Schools: http://www.soe.ecu.edu/vr/reas.html 1 (1995 (Revised 2000)).

[4] M. C. Salzman, C. Dede, R. B. Loftin, and J. Chen, A Model for Understanding How Virtual Reality Aids Complex Conceptual Learning, Presence 8 (1999) PP 293-316.

[5] R. C. Schank, The Virtual University, CyberPsychology \& Behavior 3 (2000) PP 9-16.

[6] Kalawsky, R.S. Exploiting Virtual Reality Techniques in Education and Training: Technological Issues.SIMA Report Series ISSN 1356-53702009 (1996).

[7] R. Azuma, Y. Baillot, R. Behringer, S. Feiner, Recent advances in augmented reality, Computer Graphics and application IEEE, 21 (6) (2001) PP $34-47$.

[8] H. Stewart-Smith, Education with Augmented Reality: AR textbooks released in Japan, "'ZDnet', 4 April 2012.

[9] A. Lubrecht, Augmented Reality for Education ''Digital Union', The Ohio State University 24 April 2012.

[10] P. Maier, and G. Klinker, Augmented Reality for teaching spatial relations, Conference of the International Journal of Arts \& Sciences (Toronto 2009).

[11] F. Mantovani, VR Learning: potentials and challenges for the use of 3D Environments in Education and training, Towards cyber Psychology: mind, cognitions and society in the internet age. Giuseppe Riva and Carlo Galimberti (Eds) (2003) PP 207 - 226.

[12] J. Elliott, L. Adams, \& A. Bruckman, No magic bullet: 3D Video Games in Education: Proceeding of ICLS Seattle, Washington (2002).

[13] H. Kaufmann, D. Schnalstics, Mathematics and geometry education with callborative augmented reality: Computers \& Graphics 27 (2003) PP 339 - 345.

[14] Y. Yair, 3D - Virtual Reality in Science Education: An Implication for Astronomy Teaching: JI of Computers in Mathematics, and Science Teaching 20(3) (2001) PP 293 - 305.

[15] J. Martin-Gutierrez, J.S. Saorin, M.Contero, M. Alcaniz, M., et al Design and Validation of an augmented book for Spatial abilities development in Engineering Students: Computers \& Graphics 34 (2010) PP $77-99$. 
[16] Z. Pan, A.D. Cheok, H. Yang, J. Zhu, et al Virtual Reality \& Mixed Reality for Learning Enironments: Computers \& Graphics 30 (2006) PP $20-28$.

[17] R.G. Richey, P.J. Daugherty \& A.S. Roath, Firm technological readiness and complementarity: capabilities impacting logistics service competency and performance. Journal of Business Logistics, 28 (1), (2007) PP 195-228.

[18] F. Wang, X. Chen, \& W. Fang. Integrating cell phones into a Chinese high school EFL classroom: Students' attitudes, technological readiness, and perceived learning. Journal of Educational Technology Development and Exchange, 4 (1), (2001) PP 91-102.

[19] T.D. Reeves, \& Z. Li. Teachers' technological readiness for online professional development: evidence from the US e-Learning for Educators initiative. Journal of Education for Teaching, 38 (4), (2012) PP 389-406.

[20] K. Shariq, E. Richard, Scott, L. Ann, M. Casebeer, A.F.M Mohsin, and G. Salman. Telemedicine and e-Health. 13 (4): (2007) PP 425-432. doi:10.1089/tmj.2006.0064.

[21] A. L. Caison, D. Bulman, S. Pai, \& P. Neville, Exploring the technology readiness of nursing and medical students at a Canadian University. Journal of interprofessional care, 22 (3), (2008) PP 283-294.

[22] M. Touré, L. Poissant, \& B.R. Swaine, Assessment of organizational readiness for e-health in a rehabilitation center, Disability and rehabilitation, 34 (2), (2012) PP 167-173.

[23] J.E Kottemann, The effects of technological, institutional and fiscal readiness on the extent of nations'e-government. Electronic Government, an International Journal, 6 (3), (2009) PP 327-341.

[24] A. Abdalla, M. Ibrahim, \& A. Ahmed, Technological readiness in the United Arab Emirates towards global competitiveness. World Journal of Entrepreneurship, Management and Sustainable Development, 9 (1), (2013) 4-13. https://doi.org/10.1108/20425 $\underline{961311315683}$

[25] J. Brach, Technological Readiness in the Middle East and North Africa-Implications for Egypt (2010).

[26] S. Hussin, M.R. Manap, Z. Amir, \& P. Krish, Mobile learning readiness among Malaysian students at higher learning institutes. Asian Social Science, 8 (12), (2012) PP 276.

[27] I. Ismail, S.N. Azizan, \& T. Gunasegaran, Mobile Learning in Malaysian Universities: Are Students Ready?. International Journal of Interactive Mobile Technologies (iJIM), 10 (3), (2016) PP 17-23.

[28] A. Parasuraman, “Technology Readiness Index (TRI): A Multiple Item Scale to Measure Readiness to Embrace New Technologies,"Journal of Services Research, 2 (4), (2000) 307-20. https://doi.org/10.1177/109467050024001

[29] P. Kline, The handbook of psychological testing (2nd ed.). London: Routledge, (2000) PP 13

\subsection{Internet pages}

Retrieved from https://3d4medical.com/lab 3 April, 2017.

Retrieved from http://www.blackcountryatelier.com/educational-advantages-of-3dprinting-in-schools/ visited $6^{\text {th }}$ April, 2014.

Retrieved from http://www.teachthought.com/the-future-of-learning/technology/ 10-ways-3d-printing-can-be-used-in-education/ $3^{\text {rd }}$ Febuary, 2017. 
Paper-3D Technological Readiness: A Northern Cyprus Perspective

\section{Authors}

Muhammad Bello Nawaila is a Nigerian teacher currently undergoing a PhD in Computer Education and Instructional Technology at Near East University, Cyprus.

Huseyin Bicen is a Cypriot and a lecture in the department of Computer and Instructional Technology, Near East University Cyprus, he is also the Director Distance Learning Centre.

Article submitted 22 September 2017. Published as resubmitted by the authors 13 December 2017. 